\title{
New Insights on the Use of Polyphenols as Natural Preservatives and Their Emerging Safety Concerns
}

\author{
Fred Kwame Ofosu ${ }^{1}$, Eric Banan-Mwine Daliri ${ }^{1}$, Fazle Elahi ${ }^{1}$, Ramachandran Chelliah ${ }^{1}$, \\ Byong-Hoon Lee ${ }^{2}$ and Deog-Hwan $\mathrm{Oh}^{1 *}$
}

${ }^{1}$ Department of Food Science and Biotechnology, College of Agriculture and Life Sciences, Kangwon National University, Chuncheon, South Korea, ${ }^{2}$ Department of Microbiology \& Immunology, McGill University, Montreal, QC, Canada

\section{OPEN ACCESS}

Edited by:

Juana Fernández-López,

Miguel Hernández University of

Elche, Spain

Reviewed by:

Guadalupe Virginia Nevárez-Moorillón,

Autonomous University of

Chihuahua, Mexico

Vânia Regina Nicoletti,

São Paulo State University, Brazil Ana C. Pinheiro,

University of Minho, Portugal

*Correspondence:

Deog-Hwan Oh

deoghwa@kangwon.ac.kr

Specialty section:

This article was submitted to

Sustainable Food Processing,

a section of the journal

Frontiers in Sustainable Food Systems

Received: 10 January 2020

Accepted: 16 October 2020

Published: 10 November 2020

Citation:

Ofosu FK, Daliri EB-M, Elahi F

Chelliah $R$, Lee $B-H$ and Oh D-H

(2020) New Insights on the Use of Polyphenols as Natural Preservatives and Their Emerging Safety Concerns. Front. Sustain. Food Syst. 4:525810.

doi: 10.3389/fsufs. 2020.525810
Polyphenols are natural high-valued secondary metabolites of plant that demonstrate strong antimicrobial potential as natural preservatives besides their well-established health promoting benefits. This review highlights the challenges, novel strategies to achieve industrial production of polyphenols and their safe use as potential alternative natural preservative. Since plant extraction presents considerable limitations of high cost due to excessive energy and solvent requirements, climate and long growth cycles, microbial biosynthesis using highly advanced omics techniques and metabolic engineering tools could provide superior alternative for commercial production of environmentally sustainable and cost-effective high-value metabolites in a short time. In spite of the many beneficial effects, some plant metabolites and polyphenol compounds at high dosage are found to be pro-oxidant or mutagenic with toxicity. Due to the controversial findings from sub-chronic and oral toxicity studies, more detailed safety and efficacy studies are needed to substantiate findings. Furthermore, extensive research efforts are required to ascertain optimal dosage for safe use in various foods to avoid potential harmful side effects.

Keywords: polyphenols, natural preservatives, microbial biosynthesis, high dose, safety

\section{INTRODUCTION}

Microbial contamination not only causes food loss and public health concerns but also affects the sensory characteristics and overall quality of food products. Spoilage and foodborne pathogenic microorganisms are one of the major causes of enormous economic losses despite several advances in food production technologies, distribution, hygiene standards, and consumer education. Food preservatives are defined as compounds that retard spoilage caused by microorganisms and other means such as oxidation. Several traditional food preservation technologies such as freezing, modified atmosphere packaging, thermal and non-thermal physical treatments (high hydrostatic pressure and pulsed electric fields) have been employed to control spoilage microorganisms and extend shelf life of products. More recently, synthetic chemical preservatives such as, nitrate, nitrite, citric acid, propionate, tartaric acid, sorbate, benzoate, sulfites, to mention a few, approved by regulatory agencies are widely used to control microbial growth (Russell, 1991; Manas and Pagán, 2005; Kuorwel et al., 2011; Silva and Lidon, 2016).

However, prolonged use of synthetic preservatives have been shown to pose severe health problems such as liver and kidney damage, gastrointestinal disorders, asthma, certain cancers, and many allergies (Varraso and Camargo, 2014; Etemadi et al., 2017). 
Consumers are becoming increasingly conscious of their health and safety and the negative health impacts of chemically synthesized antimicrobials. Due to the increasing demand for minimally processed and healthier foods, the use of natural antimicrobials rather than synthetic preservatives for food preservation is highly sought after by both consumers and food manufacturers (Rico et al., 2007; Bouarab-Chibane et al., 2019a). Phenolic compounds are well documented for their antibacterial activities, besides their antioxidant, antidiabetic, anti-inflammatory, antihypertensive, anticancer, immune enhancing, and cognitive function that are beneficial for optimal health (Milner and Goldberg, 1994; Sun et al., 2017; Araya-Cloutier et al., 2018). A number of reviews on specific biological activities of polyphenols have been reported elsewhere and can be referred to for more details (Duthie and Brown, 1994; Pasinetti and Ho, 2010; Salehi et al., 2018).

Extracts of plant origin are rich sources of polyphenols. Numerous studies have elucidated the antimicrobial activities of various plant extracts, hence, their potential as target alternatives for synthetic preservatives. Owing to this growing interest, several governments and companies are investing heavily for the development of natural food preservatives (Carocho et al., 2014). Currently, commercial production of polyphenols is largely dependent on plant extraction and chemical synthesis (Figure 1). However, plant extraction has considerable limitations of high cost due to excessive energy and solvent requirements, climate and long growth cycles. Microbial biosynthesis using highly advanced omics techniques and system metabolic engineering tools could provide superior alternative for large scale production of environmentally sustainable and cost-effective high-value metabolites in a short time frame to address the increasing demand of the food and nutraceutical market (Schempp et al., 2017; Ong et al., 2018; Zhao and Li, 2018). In spite of the beneficial effects, some plant metabolites and polyphenol compounds at high dosage are found to be pro-oxidant or mutagenic with toxicity (Cory et al., 2018). Due to the controversial results from sub-chronic and oral toxicity studies, more detailed safety and efficacy studies are needed to substantiate findings. Moreover, extensive research efforts are required to ascertain optimal dosage for safe and beneficial use in various foods to avoid potential harmful side effects. This review highlights the current challenges, novel design and strategies to achieve commercial production of polyphenols using advanced systems metabolic engineering tools and their use as alternative natural food preservatives. Furthermore, the safety and potential health risks associated with high dosage polyphenol consumption in food applications are discussed.

\section{CHEMISTRY AND CLASSIFICATION OF POLYPHENOLS}

Plant-derived antimicrobials are promising natural preservatives considered safe, healthy and possess additional properties from their bioactivity and nutritional value. Traditionally, plant extracts have been consumed by mankind for centuries. Polyphenols are secondary plant metabolites derived from shikimate and or the polyketide pathway. They vary widely within different plants and play key roles in pigment formation, resisting environmental stresses including defense mechanisms against pathogens or ultraviolet radiation, and acting as chemical messengers. They consist of one or more aromatic rings with hydroxyl groups attached as shown in Figure 2 (Fantini et al., 2015; Lyu et al., 2019).

Polyphenols are highly diverse, numerous and widely distributed in plants. Their structure and content are greatly affected by environmental conditions and plant species. Over 10,000 phenolic compounds are presently identified, with flavonoids constituting the largest group. They are largely found in foods such as fruits, vegetables, whole grains, coffee, wine, tea, and chocolate. Polyphenols are generally categorized according to their source of origin, structural differences, and biological activity. Therefore, polyphenols can be grouped into phenolic acids, flavonoids, lignans, stilbenoids, coumarins, and tannin polymers (Table 1). These naturally occurring compounds exist as glycosides with various sugar molecules and their acylated forms attached at different positions in the carbon skeleton (Naczk and Shahidi, 2004; Tsao, 2010; Liu, 2013). Polyphenol classification and their sources are shown in Table $\mathbf{1 .}$

\section{ANTIMICROBIAL ACTIVITIES OF POLYPHENOLS}

Globally, antibiotic resistance has been one of the serious health problems over the past few decades. Harvey et al. (2015) disclosed that more than $70 \%$ of pathogenic bacteria have shown resistance to antibiotic treatment. This has untold public health impact and together with other findings has necessitated the urgent search for novel antimicrobial compounds. Since time immemorial, plants have long been used as food and medicine for humans (Duthie and Brown, 1994). Numerous studies have demonstrated antimicrobial activities from several plants and their extracts (Savoia, 2012). Naturally occurring compounds including phenolic secondary metabolites (polyphenols), terpenoids, alkaloids, and peptides have been reported to exhibit antimicrobial properties (Cowan, 1999; Gibbons, 2008; Obied, 2013; Reichling, 2018). These plant metabolites have been found to elicit both direct and indirect inhibitory activities against efflux pump, biofilm formation, and or quorum sensing (Savoia, 2012).

Recently, (Bouarab-Chibane et al., 2019b) designed a quantitative model to establish the structure-activity relationship between polyphenols and pathogenic or food spoilage bacteria. These authors predicted the mechanisms of toxic action of 35 polyphenols $\left(1 \mathrm{~g} \mathrm{~L}^{-1}\right)$ against Gram-positive (Staphylococcus aureus, Bacillus subtilis, and Listeria monocytogenes) and Gram-negative (Escherichia coli, Pseudomonas aeruginosa, and Salmonella enteritidis) bacteria. Their findings revealed a strong interaction between bacterial cell surface and polyphenols in the exertion of antibacterial activity. This was mainly attributed to the lipophilicity, electronic and charge properties of the polyphenols. Furthermore, they also observed a strain and dose-dependent effect of polyphenols. 


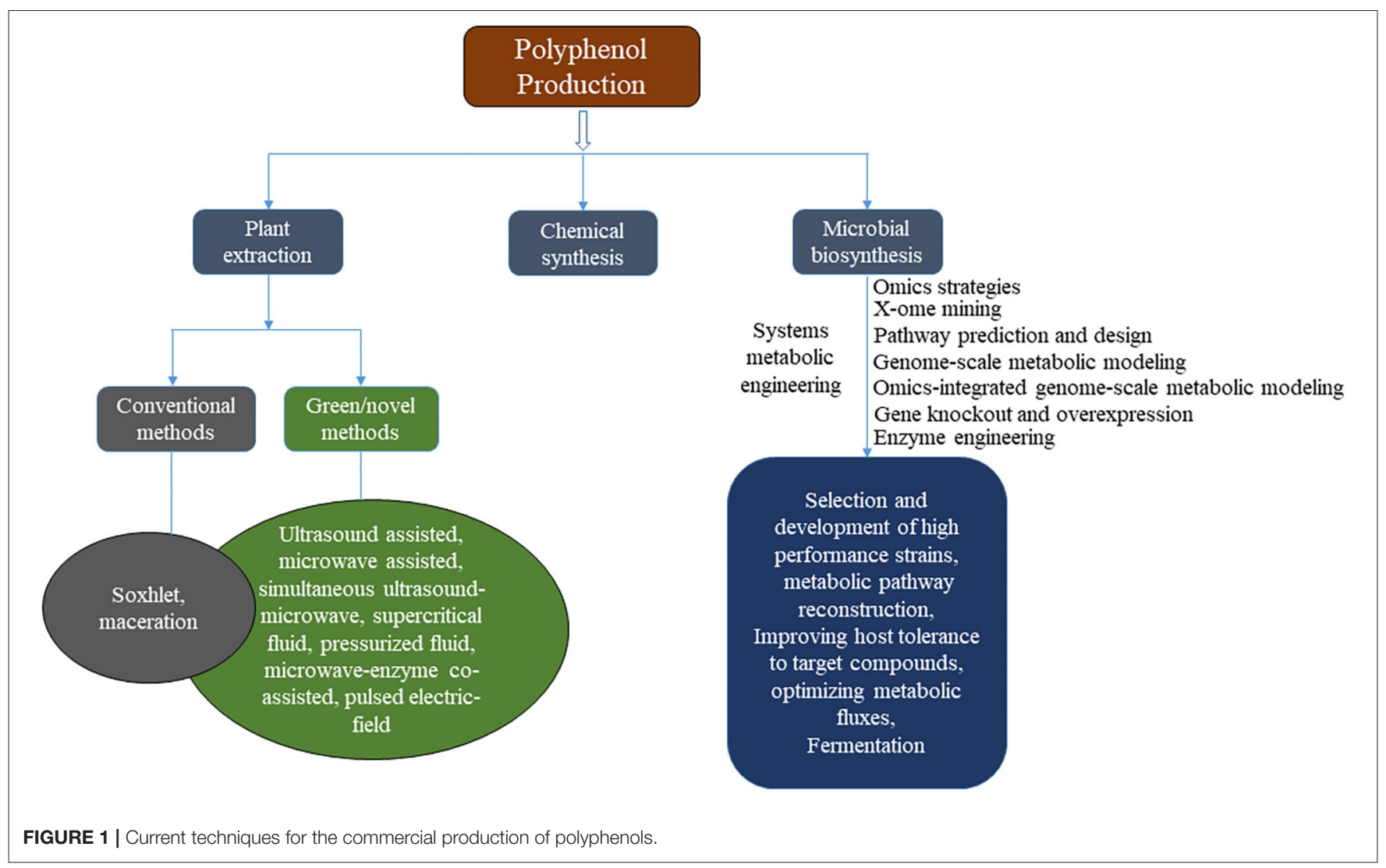

They found that L. monocytogenes was sensitive to polyphenols whereas $P$. aeruginosa was not. Strong antibacterial effect was demonstrated by 5,8-dihydroxy-1,4-naphthoquinone and butyl gallate against five out of the six bacterial strains. However, further investigations on surface properties of bacteria with other techniques besides adhesion of microorganisms to solvents are needed. Generally, extracts have shown stronger antimicrobial potency than individual polyphenols. In addition, the antimicrobial properties of plant extracts also depend on extraction solvent polarity, composition, concentration, and the type of pathogen used. Different research groups have reported the antimicrobial properties of olive leaf polyphenol extracts (Markin et al., 2003; Pereira et al., 2007; Sudjana et al., 2009; Lee and Lee, 2010; Karygianni et al., 2014; Lim et al., 2016). Wine polyphenols were found to exhibit antibacterial effect against pathogenic E. coli and L. monocytogenes in fish and could find application in the preservation of fish (RodríguezVaquero et al., 2013). Recently, Aziz and Karboune (2018) extensively reviewed the application of natural antimicrobials from plant (phenolic extracts and essential oils), animal (peptides and lactoperoxidase system), and microbial origin (chitosan, bacteriocins, bacteriophages, fermented ingredients) for prolonging the shelf life of fruits, vegetables, and meat products. Flavonoid rich green tea and grape seed extracts containing flavanols such as epicatechin, catechin, epicatechin gallate, procyanidin oligomers, and epigallocatechin were reported to control the growth of pathogenic bacteria in meat products. Cooked beef samples treated with $1 \%$ grape seed extracts (GSE) significantly reduced E. coli O157:H7 and Salmonella typhimurium counts and controlled the growth of L. monocytogenes and Aeromonas hydrophila (Ahn et al., 2007). With minimum inhibitory concentrations (MICs) below $10 \mu \mathrm{g}$ phenol $/ \mathrm{mL}$ and $15 \%$, cranberry extract with proanthocyanidins as its main antimicrobial compound showed strong inhibitions against several pathogenic bacteria including E. coli O157:H7 EDL 933, E. coli ATCC 25922, L. monocytogenes HPB 2812, P. aeruginosa ATCC 15442, Klebsiella pneumoniae, S. Typhimurium SL1344, Enterococcus faecium, Enterobacter aerogenes, and S. aureus ATCC 29213 (Sagdica et al., 2006; Côté et al., 2011).

Akhtar et al. (2019) investigated the antimicrobial properties of phenolic extracts of different spices and herbs in minced beef during refrigeration storage $\left(4^{\circ} \mathrm{C}\right)$. The methanolic extracts of ginger and coriander showed the highest total phenolic content (TPC) of 70.8 and $69.8 \mathrm{mg} \mathrm{GAE} / 100 \mathrm{~g}$, respectively. They found that ginger and coriander extracts at a concentration of $6 \%$ significantly inhibited the growth of $S$. aureus $(0.24 ; 0.32$ $\log 10 \mathrm{CFU} / g$, repectively) and E. coli $(0.23 ; 0.36 \log 10 \mathrm{CFU} / \mathrm{g}$, respectively) compared to the antibiotic, gentamycin $(0.60 ; 0.77$ $\log 10 \mathrm{CFU} / \mathrm{g}$, respectively) in minced beef stored at $4^{\circ} \mathrm{C}$ for 9 days and could be developed as natural preservatives. Ghosia et al. (2019) illustrated the antioxidant and antibacterial properties of the leaves, roots and bark of daphne mucronata plant extracts. The antibacterial activity of methanolic extracts of roots, bark and leaves was stronger compared to other solvents. The methanolic, hexane, chloroform and ethyl acetate extracts of the roots against Acinetobacter baumannii was $86.95,78.26,60.86$, and $69.56 \%$, 


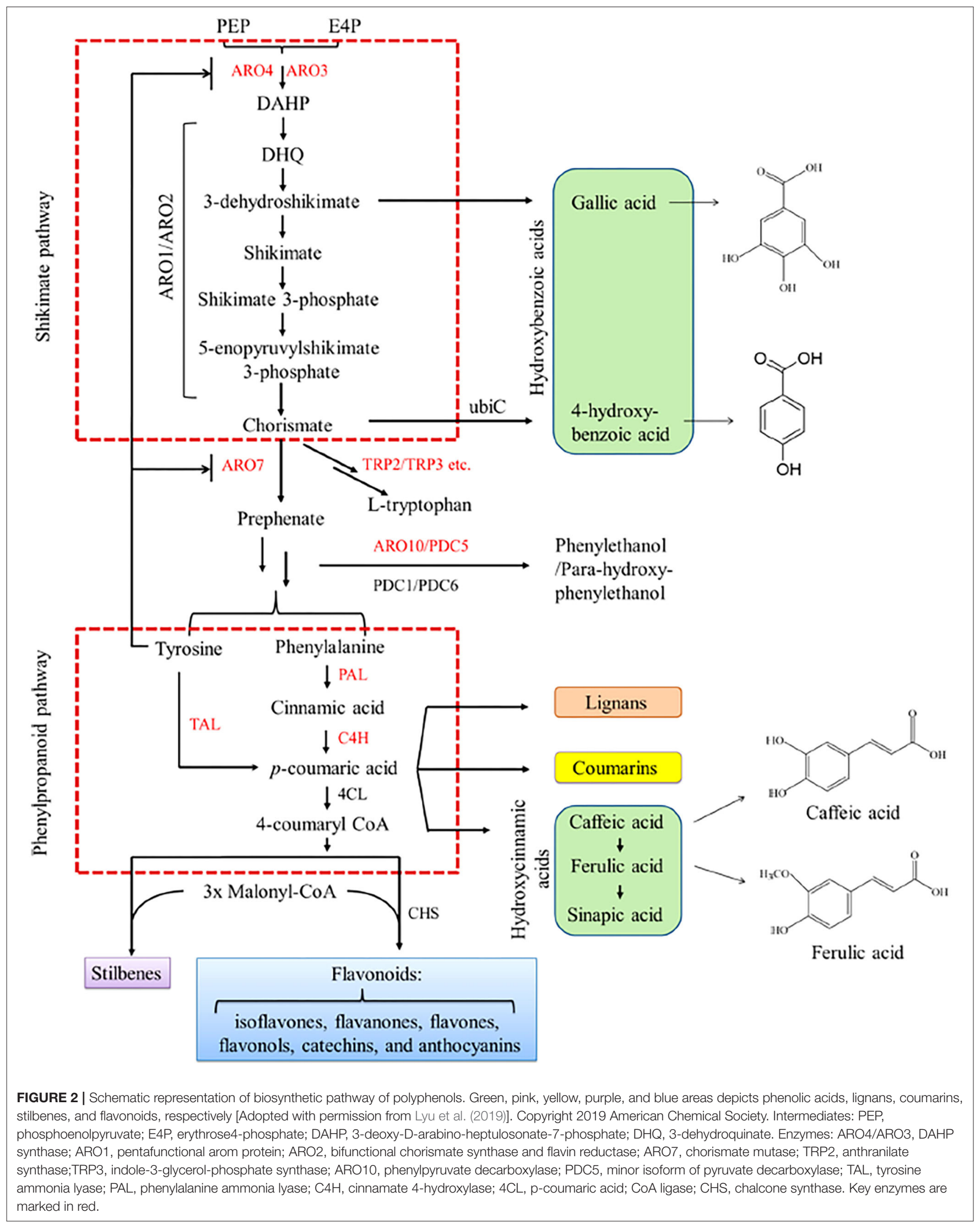


respectively. The hexane and chloroform root extracts did not show any activity against E. coli. However, methanolic and ethyl acetate root extracts showed 85.18 and $62.96 \%$ activity, respectively, against E. coli. Moreover, S. aureus was strongly inhibited by methanolic (84.61\%), chloroform (61.53\%) and ethyl acetate root extracts (69.23\%). Good activity of methanolic leave extracts was exhibited against A. bumanni (78.26\%), E. coli (77.78\%) and S. aureus (73.07\%). They also found moderate activity of methanolic bark extracts against A. bumanni (65.21\%) and E. coli (62.96\%). Furthermore, a good antioxidant activity with $\mathrm{EC}_{50}$ values ranging from 157.82 to $361.61 \mu \mathrm{g} / \mathrm{ml}$ was obtained for the extracts. It is worthy to note the antimicrobial activities of Azadirachta indica (A. indica) phenolic extracts evaluated by Ouerfelli et al. (2019) on shelf-life stability of raw beef patties during storage at $4^{\circ} \mathrm{C}$ for 11 days. A. indica leaf extracts was found to inhibit microbial growth and retard lipid oxidation of chilled beef patties. A. indica extracts showed no activity on Listeria and $B$. cereus strains. However, strong antimicrobial activity was observed against E. coli and S. aureus with an inhibition zone of 21 and $19 \mathrm{~mm}$, respectively. Moderate activity was obtained against Micrococcus luteus and Salmonella paratyphi with inhibition zones of 12 and $10 \mathrm{~mm}$, respectively. Beef samples treated with $0.7 \%(\mathrm{w} / \mathrm{w})$ fresh powdered $A$. indica leaves retarded the growth of mesophilic bacteria $\left(<10^{4} \mathrm{CFU} / \mathrm{g}\right)$ compared to the control without treatment $\left(4.2 \times 10^{4} \mathrm{CFU} / \mathrm{g}\right)$ after 11 days refrigeration storage $\left(4^{\circ} \mathrm{C}\right)$. Findings from these studies can be used to assess the safety of these extracts in different food applications to ascertain their beneficial use and consumer safety.

\section{POLYPHENOL EXTRACTION FROM PLANT SOURCES}

As mentioned earlier, plants represent an abundant resource for polyphenol-rich metabolites synthesized during their growth and under stressful environmental conditions. Literature is replete with numerous studies on the extraction of polyphenols from diverse plant materials. Generally, these phytochemicals are extracted from either fresh or dried plant sources prior to their utilization as food ingredients or in nutraceutical, pharmaceutical, and cosmetic products. Because of the diverse composition and structural differences of polyphenols in various plant materials and the varying nature of plant matrix, the establishment of a standard protocol for extracting all target metabolites from plant sources remains a huge challenge. The type of solvent, plant to solvent ratio, extraction time, temperature and agitation rate are among several parameters or conditions that affect the efficiency of the extraction process (Jovanović et al., 2017; Asofiei et al., 2019). Recent years has seen the development of more efficient extraction techniques, owing to the low efficiency of conventional methods such as maceration, Soxhlet extraction and percolation with long extraction times, large solvent volume, high temperatures and polyphenol degradation. These extraction methods include ultrasound and microwave assisted, simultaneous ultrasound-microwave assisted, supercritical and pressurized fluid, microwave and enzyme co-assisted, and pulsed electric-field. Compared to the conventional methods, these novel methods have the advantages of a shorter extraction time, reduced solvent usage, reduced thermolabile polyphenolic compound degradation, less laborious, environmentally friendly, and reduced energy and operational cost (Ameer et al., 2017; Jovanović et al., 2017; Asofiei et al., 2019). Asofiei et al. (2019) developed an efficient semicontinuous microwave assisted extraction of polyphenols from sea buckthorn leaves using a modified standard reactor. The total phenolic content (TPC) increased from 144.66 to $176.66 \mathrm{mg}$ GAE/g using microwave assisted extraction at a solvent flow rate of $6 \mathrm{ml} / \mathrm{min}$. TPC was found to increase with increasing stirring rate using larger magnetic stirrer. In addition, pre-heating of solvent $\left(50 \%\right.$ ethanol) at $60^{\circ} \mathrm{C}$ increased polyphenol extraction efficiency by $80 \%$. Comparatively, the antioxidant capacity of sea buckthorn leaves from microwave assisted extracts $(405.88 \mathrm{mg}$ $\mathrm{TE} / \mathrm{g}$ ) was higher than the conventional extracts $(354.56 \mathrm{mg}$ $\mathrm{TE} / \mathrm{g})$. Furthermore, the composition of phytochemicals was not affected by the optimized semi-continuous microwave assisted process. Compared with the conventional extraction, the developed semi-continuous microwave assisted extraction resulted in a significantly lower energy consumption. However, the optimization of extraction kinetic parameters or conditions, taking into consideration plant matrices and the composition and structure of compounds of interest are some bottlenecks for industrial scale up. In addition to the aforementioned, the impact of climate change and long growth cycles poses significant limitations to polyphenol extraction from plants for commercialization.

\section{BIOSYNTHESIS AND METABOLIC ENGINEERING FOR PRODUCTION OF POLYPHENOLS}

Literature on the biosynthesis of polyphenols has been thoroughly discussed by other authors (Knaggs, 2001; Tsao, 2010; Lyu et al., 2019) and because of that only a summary will be given in this work. In plants and microbes, the shikimate and phenylpropanoid metabolic pathways represent the main routes for polyphenol biosynthesis (Figure 2). The central carbon metabolism is linked to aromatic amino acids biosynthesis via the shikimate pathway. Shikimate intermediates such as chorismate are key precursors for the biosynthesis of various aromatic compounds including phenylalanine, tryptophan, tyrosine and polyphenolic compounds (Herrmann, 1995). Intermediates from the phenylpropanoid pathway such as 4coumaroyl CoA serves as good precursors for the biosynthesis of complex polyphenols such as flavonoids and stilbenes (Lyu et al., 2019). Hence, gaining a complete understanding of polyphenol biosynthesis pathways and developing efficient strategies for their production is extremely important for the de novo synthesis of diverse high value metabolites for industrial applications.

Metabolic engineering is a technique used to manipulate and optimize genetic and regulatory processes in living organisms to increase the production of target metabolites. Metabolically engineered microbes have gained increasing attention in pharmaceutical, nutraceutical and food applications. In recent years, the development of high-performance strains 
TABLE 1 | Classification of polyphenols and their sources [adapted and modified from Papuc et al. (2017)].

Class name and backbone structure

\section{Phenolic acids}<smiles>O=C(O)c1ccccc1</smiles><smiles>O=C(O)/C=C/c1ccccc1</smiles>

Cinnamic acid

\section{Flavonoids}<smiles>[R1]c1cc(-c2[o+]c3cc(O)cc(O)c3cc2O)cc([R1])c1[R2]</smiles>

Cyanidin

Pelargonidin

Petunidin

Malvidin

Delphinidin

Peonidin
Fruits, vegetables, cereals, red and blue flower petals
References

Fruits, vegetables and cereals

Fruits, vegetables, cereals, coffee

Manach et al., 2004; Ofosu et al., 2020

Rice-Evans et al., 1996;

Manach et al., 2004

Mazza and Francis, 1995; Bravo, 1998; Pietta, 2000

Anthocyanin<smiles>O=c1cc(-c2ccccc2)oc2ccccc12</smiles>

Luteolin

Apigenin

Chrysin

Baicalein

Alfalfa

Indian trumpet flower

Kawaii et al., 1999; Chen et al., 2003; El-Shafey and Abdelgawad, 2012;

Mishima et al., 2015; Kim et al., 2016

Hesperetin

Naringenin

Citrus and

grapefruit peels

Lien et al., 2008; Mullen et al., 2008; Tomas-Navarro et al., 2014

Propolis, honey, fruits, vegetables, cereals

Kaempferol

Galangin

Fisetin

Myricetin

Morin

(+)-Catechin

$(-)$-Epicatechin

(-)-Epigallocatechin

(-)-Epicatechin-3-gallate

(-)-Epigallogatechin-3-

gallate

Chan et al., 2007; Bertelli et al., 2012; Kurtagić et al., 2013
Green tea, black tea, cocoa, cereals
Zaveri, 2006; Subhashini et al., 2010; Gadkari and Balaraman, 2015

Flavan-3-ol 
TABLE 1 | Continued

\begin{tabular}{|c|c|c|c|}
\hline $\begin{array}{l}\text { Class name and backbone } \\
\text { structure }\end{array}$ & Examples & Sources & References \\
\hline & $\begin{array}{l}\text { Genistein } \\
\text { Genistin } \\
\text { Daidzein } \\
\text { Daidzin } \\
\text { Biochanin A } \\
\text { Formononetin }\end{array}$ & Legumes, red clovers & $\begin{array}{l}\text { Wang and Murphy, 1994; } \\
\text { Mazur et al., 1998; Dixon } \\
\text { and Ferreira, 2002; Tsao } \\
\text { et al., 2003; Kim et al., } \\
\text { 2012; Kuligowski et al., } \\
2017\end{array}$ \\
\hline & $\begin{array}{l}\text { Isoliquiritigenin } \\
\text { Flavokawain A } \\
\text { Flavokawain B } \\
\text { Flavokawain C } \\
\text { Gymnogrammene }\end{array}$ & $\begin{array}{l}\text { Apples, flowers, } \\
\text { hop, beer }\end{array}$ & $\begin{array}{l}\text { Tsao et al., 2003; Tsao and } \\
\text { McCallum, 2009; Aksöz and } \\
\text { Ertan, 2012; Suwito et al., } \\
2014\end{array}$ \\
\hline & $\begin{array}{l}\text { trans-Resveratrol } \\
\text { trans-Piceatannol } \\
\text { trans-Piceid } \\
\text { trans-Pterostillbene } \\
\text { Cajanotone } \\
\text { Cajanamide }\end{array}$ & $\begin{array}{l}\text { Red grapes, wine, } \\
\text { blueberries, } \\
\text { peanuts, dark } \\
\text { chocolate, Cajanus cajan, } \\
\text { sorghum }\end{array}$ & $\begin{array}{l}\text { Sanders et al., 2000; Burns } \\
\text { et al., 2002; Lyons et al., } \\
\text { 2003; Counet et al., 2006; } \\
\text { BröHan et al., 2011; Zhang } \\
\text { et al., } 2012\end{array}$ \\
\hline
\end{tabular}

\section{Lignan}

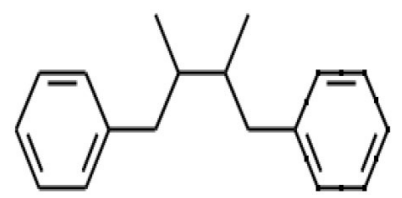

Sesamin

Matairesinol

Pinoresinol

Medioresinol

Flax seed, sesame seed, fruits, vegetables, legumes and many grains

Fruits, flowers, seeds

Ostruthin

Ammoresinol

Anthogenol

Felamidin

Agasyllin
Mazur et al., 1998; Milder et al., 2005; Peñalvo et al., 2005; Smeds et al., 2007 , 2012 has seen tremendous acceleration with the emergence of systems metabolic engineering. This interdisciplinary field employs new tools and strategies from systems biology, synthetic biology and evolutionary engineering with conventional metabolic engineering (Choi et al., 2019). Recent reviews have focused on sustainable biosynthesis of polyphenols in bioengineered yeast; advances in tools and strategies for systems metabolic engineering with significant potential for industrial applications (Choi et al., 2019; Lyu et al., 2019).

Several microrganisms have been engineered to synthesize various polyphenols. The advantages of using bioengineered microorganisms over enzymatic and chemical syntheses for production of natural products include but are not limited to inexpensive cofactor requirement, and specific regioselectivity and stereoselectivity. E. coli, Saccharomyces cerevisiae and Corynebacterium glutamicum with GRAS (generally regarded as safe) status have been widely used as microbial cell factories to produce diverse high-value compounds. Nevertheless, industrial application of polyphenols produced using metabolic engineered microbes still faces quite a number of challenges. The limitation of low productivity or yield, high toxicity to cell growth or low host tolerance to target compounds and expensive feedstock supply poses significant difficulty for their commercial production (Lyu et al., 2019). The development of highly advanced omics techniques and systems metabolic engineering tools is expected to unveil and provide a complete understanding of polyphenol biosynthesis pathways needed to circumvent microbial biosynthesis productivity challenges. Choi et al. 
(2019) provides a thorough description of the selection and improvement of high performance strains using novel design and strategies in genetic and genomic engineering, in silico metabolic simulation and high-throughput screening to reconstruct metabolic pathways, increase host tolerance and optimize metabolic fluxes for enhanced target compound production. Chung et al. (2017) used plant aromatic aldehyde synthase (AAS) and uridine diphosphate-dependent glycosyltransferases (UGTs) to synthesize polyphenols in E. coli. Using engineered E. coli harboring AAS and 12 UGTs, tyrosol, hydroxytyrosol and salidroside were synthesized at 531, 208, and 288 $\mathrm{mg} / \mathrm{L}$, respectively. When glucose was used as carbon source, naringenin was produced in E. coli at a titer of $29 \mathrm{mg} / \mathrm{L}$ (Santos et al., 2011). Other studies have reported the production of flavonoids; kaempferol, quercetin and fisetin using $p$ coumaric acid and L-tyrosine as precursor in E. coli, respectively (Leonard et al., 2006; Stahlhut et al., 2015). Rodriguez et al. (2017) reported the synthesis of the flavonoids; naringenin, liquiritigenin, kaempferol, resokaempferol, quercetin, and fisetin in an engineered S. cerevisiae directly from glucose. Generally, extracts have shown stronger antimicrobial potency than individual polyphenols. Compared to pure flavonoids and phenolic acids, phenolic compounds (naringenin, phloretic acid, phenylacetaldehyde, and homogentisic acid) from engineered $S$. cerevisiae strain $\mathrm{N} 2$ was found to exert more potent antibacterial activity against pathogenic E. coli ATCC 25922 and S. aureus ATCC 29213 (Ng et al., 2019). N2 extracts of concentrations up to $400 \mu \mathrm{g}$ showed inhibition zones of 4 and $8.33 \mathrm{~mm}$ against E. coli ATCC 25922 and S. aureus ATCC 29213, respectively. On the contrary, pure naringenin did not show any inhibition against either strains, while 6-prenylnaringenin and 8-prenylnaringenin demonstrated inhibition zones of 4 and $7.67 \mathrm{~mm}$ against $S$. aureus, respectively. It is therefore imperative to show the safety of these extracts in human trials to prove their viability as food preservatives. Using engineered C. glutamicum, Kallscheuer et al. (2016) produced resveratrol at titers of $5 \mathrm{mg} / \mathrm{L}$ independent from endogenous aromatic amino acid pathway. Using a different strategy which avoided ammonia lyase activity, a rate limiting step in microbial synthesis, the authors reversed the $\beta$-oxidative phenylpropanoid degradation pathway and could produce polyphenols from cheap benzoic acids. A more recent review by Kogure and Inui (2018) summarizes the potential of metabolically engineered C. glutamicum for commercial production of several valuable aromatic and natural products including plant polyphenols at high titer from renewable feedstocks.

\section{POLYPHENOL SAFETY EVALUATION AND FUTURE PERSPECTIVES}

It is a common believe that compounds from natural sources are safe, even at high doses. Thus, the limited evidence in literature regarding toxicity of natural plant extracts. Moreover, the safety aspects on the long term consumption of high doses of polyphenols either as dietary supplements or food additives is not clearly known in humans and needs to be thoroughly investigated. Although numerous animal studies have confirmed the beneficial role of polyphenols, findings from several subchronic and oral toxicity studies, still remain controversial (Table 2). Therefore, assessing the safe levels of polyphenols and other natural compounds for use as food preservatives is crucial for determining potential cytotoxicity. Findings from Yamakoshi et al. (2002) showed a lack acute and subchronic toxicity of proanthocyanin-rich grape seed extracts adminsistered orally in rats at high doses of 2 and $4 \mathrm{~g} / \mathrm{kg}$. They found the lethal dose to be higher than $4 \mathrm{~g} / \mathrm{kg}$ in the acute study on the 14th day of clinical observation. However, the no-observed-adverse effect level (NOAEL) during 90 days subchronic toxicity study was found to be $2 \mathrm{~g} / \mathrm{kg}$ of GSE (about 240 times the estimated daily proanthocyanidin intake by humans). Grape seed polyphenolic extract (GSPE) has shown high tolerability and found to be safe in animal models fed with chow and extract in a 90 days subchronic toxicity study. No detectable adverse effects were observed after treatment with doses from 200 to $2150 \mathrm{mg} / \mathrm{kg} /$ day (Bentivegna and Whitney, 2002; Wang et al., 2008). Moreover, treatment of pre-hypertensive people with GSPE $300 \mathrm{mg} /$ day showed a significant reduction in blood pressure with no observed adverse effects (Sivaprakasapillai et al., 2009). This evidence suggests the safety and tolerability of GSPE for treatment in humans. In addition, Charradi et al. (2018) have reported the safety of high repeated dosing of GSPE ( 8 and $16 \mathrm{~g} / \mathrm{kg} \mathrm{bw}$ ) fed to healthy rats for 2 months. Their findings showed no toxicity and support the potential applications in different foods for biotic or abiotic stress-induced multi-organ dysfunction. European Food Safety Authority (EFSA) Panel on Additives and Products or Substances used in Animal Feed (FEEDAP) has established the safety and efficacy of dry grape extract used as feed flavoring for all animals and categories except dogs at a maximum level of $100 \mathrm{mg} / \mathrm{kg}$ complete feed. The panel emphasized no safety concerns for consumers at this level in feeds (EFSA FEEDAP Panel (EFSA Panel on Additives and Products or Substances used in Animal Feed), 2016). Despite these results, more detailed safety and efficacy human studies are needed to substantiate findings for other plant extracts.

On the contrary, certain studies have delineated the prooxidant and adverse effect of plant metabolites and polyphenol compounds (Galati et al., 2002; Shao et al., 2003). Thus, it is imperative to mention that natural compounds may not be safe as previously thought at high concentrations and cause deleterious effects to humans (Li et al., 2008). Higher doses of GSPE (100 or $500 \mu \mathrm{g} / \mathrm{mL}$ ) showed pro-oxidant effects and toxicity to cells (Shao et al., 2003). According to a recent systematic review on toxicological studies on green tea extracts (rich in catechin phenolic profiles) by Oketch-Rabah et al. (2020), adverse effects of hepatotoxicity was associated with (-)-epigallocatechin-3gallate (EGCG) consumption from $140 \mathrm{mg}$ to $1,000 \mathrm{mg} /$ day. The authors also concluded that individual genetic susceptibility and underlying liver health could contribute to these effects and that product label should include caution of usage.

Therefore, extensive research efforts in humans are required to ascertain optimal dosage for safe use to avoid potential harmful side effects. Likewise, recent advances in omics tools and strategies, together with more carefully designed animal 
TABLE 2 | In-vivo and in-vitro studies on the safety and toxicity potential of polyphenol consumption.

\begin{tabular}{|c|c|c|c|c|c|}
\hline Plant source & Major polyphenol & $\begin{array}{l}\text { Duration of } \\
\text { intervention/Cell lines }\end{array}$ & Purpose of the study & Clinical outcomes & References \\
\hline Grape seed extracts (GSE) & Proanthocyanidin & 90 days & $\begin{array}{l}\text { Examined GSE for acute and subchronic } \\
\text { oral toxicity in Fischer } 344 \text { rats and their } \\
\text { mutagenicity potential. }\end{array}$ & $\begin{array}{l}\text { No evidence of mutagenicity and acute oral toxicity } \\
\text { at doses of } 2 \text { and } 4 \mathrm{~g} / \mathrm{kg} \text {. } 2 \% \text { ( } \mathrm{w} / \mathrm{w} \text { ) GSE was the } \\
\text { NOAEL in subchronic toxicity study. Lack of toxicity } \\
\text { of GSE. }\end{array}$ & Yamakoshi et al., 2002 \\
\hline $\begin{array}{l}\text { Unripe Apple polyphenol } \\
\text { extract }\end{array}$ & $\begin{array}{l}\text { Procyanidins, epicatechin, } \\
\text { catechin, chlorogenic acid, } \\
\text { phloridzin }\end{array}$ & 90 days & $\begin{array}{l}\text { Evaluated the mutagenicity, genotoxicity, } \\
\text { the acute oral and subchronic toxicity of } \\
\text { Applephenon in Sprague-Dawley rats. }\end{array}$ & $\begin{array}{l}\text { Lethal dose of }>2 \mathrm{~g} / \mathrm{kg} \text { in acute oral toxicity in both } \\
\text { male and female rats. No abnormal hematological, } \\
\text { clinical, histopathological or urinary effects at a dose } \\
\text { of } 2 \mathrm{~g} / \mathrm{kg} \text { in subchronic oral toxicity study. }\end{array}$ & Shoji et al., 2004 \\
\hline $\begin{array}{l}\text { Capparis spinosa L. leave } \\
\text { extracts }\end{array}$ & $\begin{array}{l}\text { Gallic acid, caffeic acid, } \\
\text { coumaric acid, ferulic acid, } \\
\text { chlorogenic acid, rutin, } \\
\text { quercetin }\end{array}$ & 3 days & $\begin{array}{l}\text { Investigated the oral acute toxicity of } \\
\text { polyphenolic extract of Capparis spinosa } \\
\text { L. leaves in female rats and in vitro } \\
\text { antibacterial effect. }\end{array}$ & $\begin{array}{l}\text { No adverse effect or mortality at doses of } 100 \\
\mathrm{mg} / \mathrm{kg} \text {. The extract showed antibacterial activity } \\
\text { against } S \text {. aureus ( } 12 \mathrm{~mm}), B \text {. subtilus ( } 11 \mathrm{~mm}), E \text {. } \\
\text { coli }(12 \mathrm{~mm}), P \text {. aeruginosa (12 mm). }\end{array}$ & Oudah et al., 2019 \\
\hline $\begin{array}{l}\text { Seventeen freshly } \\
\text { prepared plant extracts, } \\
\text { two commercial plant } \\
\text { extracts, naringin, } \\
\text { kaempferol and } \\
\text { resveratrol. }\end{array}$ & Not provided & $\begin{array}{l}\text { HepG2, Caco-2, A549, } \\
\text { HMEC-1, and } 3 \text { T3 cell } \\
\text { lines. }\end{array}$ & $\begin{array}{l}\text { Screened the toxicity potential of } 22 \\
\text { polyphenol-rich compounds on } \\
\text { mitochondrial membrane potential, cell } \\
\text { membrane integrity and nuclear size } \\
\text { using high content analysis. }\end{array}$ & $\begin{array}{l}\text { Buckthorn bark, walnut husk and hollyhock extracts } \\
\text { showed high cytotoxicity to mitochondrion and cell } \\
\text { membrane but not the nucleus. On the contrary, } \\
\text { spent hop and kale leaf extracts showed low } \\
\text { cytotoxicity to mitochondrial membrane, cell } \\
\text { membrane integrityand nuclear area. Kaempferol } \\
\text { exerted strong toxicity on mitochondrial and nuclear } \\
\text { compartments whiles naringin showed least } \\
\text { cytotoxicity. }\end{array}$ & Boncler et al., 2017 \\
\hline Green tea & Epigallocatechin gallate (EGCG) & 30 days & $\begin{array}{l}\text { Examined the safety and } \\
\text { pharmacokinetics of chronic green tea } \\
\text { polyphenol or polyphenon E } \\
\text { consumption in healthy men and women } \\
\text { with Fitzpatric skin type II or III. }\end{array}$ & $\begin{array}{l}\text { Mild effects of excess gas, stomach upsets, } \\
\text { heartburn, abdominal pain, headache, dizziness and } \\
\text { muscle pain at doses of } 800 \mathrm{mg} \text { EGCG once/day or } \\
400 \mathrm{mg} \text { EGCG twice/day in treated group. Daily dose } \\
\text { of } 800 \mathrm{mg} \text { EGCG was safe and well-tolerated and } \\
\text { resulted in > } 60 \% \text { increase in systemic EGCG but did } \\
\text { not provide protection against UV-induced erythema. }\end{array}$ & Chow et al., 2003 \\
\hline Green tea & $\begin{array}{l}\text { Epigallocatechin-3- gallate } \\
\text { (EGCG), propyl gallate, } \\
\text { epicatechin-3-gallate, } \\
\text { epigallocatechin, epicatechin, } \\
\text { gallic acid }\end{array}$ & 1 day/rats hepatocytes & $\begin{array}{l}\text { Examined the cytotoxicities of major tea } \\
\text { phenolics on isolated rat hepatocytes } \\
\text { and its hepatotoxicity in mice } \\
\text { administered intraperitoneally. }\end{array}$ & $\begin{array}{l}\text { Tea phenolics showed cytotoxicity on hepatocytes. } \\
\text { Epigallocatechin-3- gallate exerted strong toxicity on } \\
\text { mitochondrial membrane collapse and inducing ROS } \\
\text { formation. Tea phenolics at doses of 50-800 mg/kg } \\
\text { caused liver injury in mice after } 24 \mathrm{~h} \text {. }\end{array}$ & Galati et al., 2006 \\
\hline Green tea extract & Epigallocatechin gallate & 13 weeks & $\begin{array}{l}\text { Evaluated the dermal, acute and } \\
\text { short-term safety studies of EGCG in } \\
\text { rats and dogs. }\end{array}$ & $\begin{array}{l}\text { Lethal dose of } 2 \mathrm{~g} / \mathrm{kg} \text {, no oral toxicity at a dose of } \\
0.2 \mathrm{~g} / \mathrm{kg} \text { in rats. The NOAEL was } 0.5 \mathrm{~g} / \mathrm{kg} / \text { day for } \\
\text { subchronic toxicity study. }\end{array}$ & Isbrucker et al., 2006 \\
\hline Herbal mixture & $\begin{array}{l}\text { Gallic acid, Cinnamic acid, } \\
\text { Coumarin, Benzoic acid, } \\
\text { Paoniflorin, Albiflorin, } \\
\text { Amygdalin, Oxypaeoniflorin }\end{array}$ & 13 weeks & $\begin{array}{l}\text { Assessed the safety of oral } \\
\text { administration of traditional herbal } \\
\text { formula of } \\
\text { Gyejibokryeong-hwan in male and } \\
\text { female Sprague-Dawley (SD) rats. }\end{array}$ & $\begin{array}{l}\text { At a dose of } 5 \mathrm{~g} / \mathrm{kg} / \text { day, ulcers and dilated stomach } \\
\text { glands were observed in males, whiles squamous } \\
\text { cell hyperplasia and epithelial atrophy in stomach } \\
\text { were observed in both male and female rats. } \\
\text { Hematological examinations showed a significant } \\
\text { increase in white blood cells, neutrophils and } \\
\text { fibrinogen at } 5 \mathrm{~g} / \mathrm{kg} / \text { day. The NOAEL was } 2 \mathrm{~g} / \mathrm{kg} / \text { day. }\end{array}$ & Jin et al., 2018 \\
\hline $\begin{array}{l}\text { Grape seed and skin } \\
\text { extracts }\end{array}$ & Proanthocyanidin & 3 months & $\begin{array}{l}\text { Investigated the subchronic oral toxicity } \\
\text { of grape seed extracts (GSE) and grape } \\
\text { skin extracts GSKE) in SD rats. }\end{array}$ & $\begin{array}{l}\text { No significant histological changes were observed in } \\
\text { all tissues. The NOAEL for male rats was } 1.78 \\
\mathrm{~g} / \mathrm{kg} / \text { day GSE or GSKE and } 2.15 \mathrm{~g} / \mathrm{kg} / \text { day GSE or } \\
\text { GSKE in female rats. }\end{array}$ & $\begin{array}{l}\text { Bentivegna and } \\
\text { Whitney, } 2002\end{array}$ \\
\hline
\end{tabular}

Gallic acid, caffeic acid

hlorogenic acid, rutin

quercetin

prepared plant extracts,

kaempferol and

resveratrol.

Green tea

Epigallocatechin-3- gallate

epigallocatechin, epicatechin,

gallic acid

Grape seed and skin 


\begin{tabular}{|c|c|c|c|c|c|}
\hline Plant source & Major polyphenol & $\begin{array}{l}\text { Duration of } \\
\text { intervention/Cell lines }\end{array}$ & Purpose of the study & Clinical outcomes & References \\
\hline Grape seed powder (GSP) & $\begin{array}{l}\text { Procyanidins, catechin, } \\
\text { epicatechin }\end{array}$ & 2 months & $\begin{array}{l}\text { Evaluated the antioxidant, } \\
\text { anti-inflammatory effects and the } \\
\text { subchronic toxicity of GSP administered } \\
\text { orally in Wistar rats. }\end{array}$ & $\begin{array}{l}\text { No adverse effects at the high dose of } 16 \mathrm{~g} / \mathrm{kg} \text {. GSP } \\
\text { reduced lipoperoxidation, increased antioxidant } \\
\text { enzyme activities (CAT, GPx and SOD), reduced } \\
\text { plasma IL17 A and CRP, increased IL10 and } \\
\text { adiponectin, improved heart and renal } \\
\text { microcirculation. }\end{array}$ & Charradi et al., 2018 \\
\hline Morus nigra L. leaves & $\begin{array}{l}\text { Quercetin, } \\
\text { caffeic acid }\end{array}$ & 28 days & $\begin{array}{l}\text { Examined the phytochemical } \\
\text { composition of ethanolic extracts of } \\
\text { Morus nigra L. leaves, their oral acute } \\
\text { and subacute toxicities in male and } \\
\text { female Wistar rats. }\end{array}$ & $\begin{array}{l}\text { Lethal dose of } 2 \mathrm{~g} / \mathrm{kg} \text { was observed in renal and } \\
\text { hepatic organs in acute studies. The NOAEL in male } \\
\text { rats was } 0.75 \mathrm{~g} \text { and } 1 \mathrm{~g} / \mathrm{kg} \text { and } 1 \mathrm{~g} / \mathrm{kg} \text { in female rats. }\end{array}$ & Figueredo et al., 2018 \\
\hline Grape seed extract & Proanthocyanidin & Chick cardiomyo-cytes. & $\begin{array}{l}\text { Investigated the effects of grape seed } \\
\text { proanthocyanidin extract (GSPE) on } \\
\text { ROS generation, cell survival, LDH and } \\
\text { caspase-3 activity using chick } \\
\text { cardiomyocytes. }\end{array}$ & $\begin{array}{l}\text { Higher doses (100 } \\
\text { or } 500 \mu \mathrm{g} / \mathrm{mL} \text { ) of GSPE increased ROS generation, } \\
\text { LDH release and caused cell death. At } 500 \mu \mathrm{g} / \mathrm{mL} \text {, } \\
\text { caspase-3 activity was significantly increased. }\end{array}$ & Shao et al., 2003 \\
\hline Vernonia mespilifolia Less. & Not provided & 28 days & $\begin{array}{l}\text { Evaluated the acute and subacute } \\
\text { toxicity of aqueous extract of Vernonia } \\
\text { mespilifolia Less in male and female } \\
\text { Wistar rats. }\end{array}$ & $\begin{array}{l}\text { Lethality dose was }>5 \mathrm{~g} / \mathrm{kg} \text { in acute toxicity (single } \\
\text { dose) study. No evidence of heart, hepatic and renal } \\
\text { toxicity at doses up to } 0.6 \mathrm{~g} / \mathrm{kg} \text { in subacute study. }\end{array}$ & Unuofin et al., 2018 \\
\hline $\begin{array}{l}\text { Olea europaea L. (olive } \\
\text { tree) }\end{array}$ & $\begin{array}{l}\text { Oleuropein, } \\
\text { hydroxytyrosol, } \\
\text { luteolin-7-glucoside, } \\
\text { apigenin-7-glucoside, } \\
\text { verbascoside }\end{array}$ & 90 days & $\begin{array}{l}\text { Investigated the genotoxicity and } \\
\text { repeated-dose oral toxicity of water- } \\
\text { soluble extract of olive tree leaves in } \\
\text { male and female Wistar rats. }\end{array}$ & $\begin{array}{l}\text { No evidence of mutagenicity and genotoxicity in mice } \\
\text { micronucleus up to doses of } 2 \mathrm{~g} / \mathrm{kg} / \text { day. No toxic } \\
\text { effects or mortality in both male and female rats at } \\
\text { high dose of } 1 \mathrm{~g} / \mathrm{kg} / \text { day in subchronic study. }\end{array}$ & Clewell et al., 2016 \\
\hline Olea europaea L. & $\begin{array}{l}\text { Oleuropein, } \\
\text { Verbascoside, hydroxytyrosol, } \\
\text { Rutin, } \\
\text { Oleanolic acid }\end{array}$ & 28 days & $\begin{array}{l}\text { Investigated the acute and subacute oral } \\
\text { toxicities of olive leaves ethanolic } \\
\text { extracts in male and female Wistar rats. }\end{array}$ & $\begin{array}{l}\text { No adverse effects or mortality was observed at a } \\
\text { single dose of } 2 \mathrm{~g} / \mathrm{kg} \text {. Subacute repeated doses up } \\
\text { to } 0.4 \mathrm{~g} / \mathrm{kg} \text { showed no toxicities in both male and } \\
\text { female rats. }\end{array}$ & Guex et al., 2018 \\
\hline Olea europaea L. & $\begin{array}{l}\text { Oleuropein, } \\
\text { Verbascoside, hydroxytyrosol, } \\
\text { Rutin, Oleanolic acid }\end{array}$ & 6 weeks & $\begin{array}{l}\text { Evaluated the effect of olive leaf extracts } \\
\text { (OLE) on liver and kidney toxicity in } \\
\text { Wistar albino rats. }\end{array}$ & $\begin{array}{l}\text { Dosage of } 0.9 \% \text { OLE showed hepatocellular and } \\
\text { renal abnormalities. }\end{array}$ & Omer et al., 2012 \\
\hline Olea europaea L. & $\begin{array}{l}\text { Oleuropein, } \\
\text { Verbascoside, hydroxytyrosol, } \\
\text { Rutin, } \\
\text { Ligstroside }\end{array}$ & 5 weeks & $\begin{array}{l}\text { Assessed the effect of OLE administered } \\
\text { orally on busulfan (BU) induced damages } \\
\text { in rat testes and the safety profile. }\end{array}$ & $\begin{array}{l}\text { OLE at doses of } 0.25,0.5 \text { and } 0.75 \mathrm{~g} / \mathrm{kg} \text { repaired } \\
\text { defects in rats testes. } 0.25 \text { and } 0.5 \mathrm{~g} / \mathrm{kg} \text { OLE } \\
\text { significantly reduced apoptotic spermatogonia cells. } \\
\text { However, OLE at a dose of } 0.75 \mathrm{~g} / \mathrm{kg} \text { increased } \\
\text { markers of liver damages (ALP and AST). }\end{array}$ & Hakemi et al., 2019 \\
\hline $\begin{array}{l}\text { Campomanesia } \\
\text { guazumifolia (Cambess.) } \\
\text { O. Berg. }\end{array}$ & $\begin{array}{l}\text { quercetin pentose, quercetin } \\
\text { deoxyhexoside, myricetin } \\
\text { deoxy-hexoside, quinic acid }\end{array}$ & 28 days & $\begin{array}{l}\text { Evaluated the toxicity and } \\
\text { anti-inflammatory activities of leave } \\
\text { extracts of } C \text {. guazumifolia in } \\
\text { female mice. }\end{array}$ & $\begin{array}{l}\text { Lethal dose of }>5 \mathrm{~g} / \mathrm{kg} \text { in acute oral toxicity. Doses } \\
\text { of up to } 1 \mathrm{~g} / \mathrm{kg} \text { did not show any histological and } \\
\text { hematological toxicity in subacute study. Doses of } \\
0.3 \mathrm{~g} \text { and } 0.7 \mathrm{~g} / \mathrm{kg} \text { showed anti-inflammatory activity } \\
\text { by reducing mechanical hyperalgesia, leukocyte } \\
\text { migration and extravasation protein in pleural cavity. }\end{array}$ & Catelan et al., 2018 \\
\hline
\end{tabular}


studies will contribute immensely to provide clearer insight into emerging safety concerns. Further works on understanding structure-activity relationship of natural antimicrobials and their mechanisms of action may help facilitate their use in different food systems, thus mitigating antibiotic resistance. Finally, in food applications regulatory authorities should assess and ensure acceptable levels for long term use to guarantee consumer safety.

\section{CONCLUSION}

Polyphenols are natural high-valued secondary metabolites with well-established benefits in human health. This had led to an increased intake of dietary polyphenol supplements. Moreover, due to the surge in demand for minimally processed and healthier foods, polyphenols have gained tremendous interest as promising alternative natural antimicrobial preservatives for inactivating spoilage and pathogenic microorganisms and to enhance microbial safety. Therefore, gaining a complete understanding of polyphenol biosynthesis pathways using highly advanced omics techniques and systems metabolic engineering tools could help circumvent microbial biosynthesis productivity challenges and provide superior alternative to plant

\section{REFERENCES}

Ahn, J., Grun, I. U., and Mustapha, A. (2007). Effects of plant extracts on microbial growth, color change, and lipid oxidation in cooked beef. Food Microbiol. 24, 7-14. doi: 10.1016/j.fm.2006.04.006

Akhtar, S., Waseem, M., Ahmad, N., Ismail,T., Ahmad, Z., Manzoor, M. F., et al. (2019). Polyphenol-rich extracts of traditional culinary spices and herbs and their antibacterial activity in minced beef. J. Food Qual. 2019:1702086. doi: $10.1155 / 2019 / 1702086$

Aksöz, B. E., and Ertan, R. (2012). Spectral properties of chalcones II. FABAD J. Pharm. Sci. 37, 205-216.

Ameer, K., Shahbaz, H. M., and Kwon, J. H. (2017). Green extraction methods for polyphenols from plant matrices and their byproducts: a review. Compr. Rev. Food Sci. Food Saf. 16, 295-315. doi: 10.1111/1541-4337.12253

Araya-Cloutier, C., Vincken, J.-P., Van Ederen, R., Den Besten, H. M., and Gruppen, H. (2018). Rapid membrane permeabilization of Listeria monocytogenes and Escherichia coli induced by antibacterial prenylated phenolic compounds from legumes. Food Chem. 240, 147-155. doi: $10.1016 /$ j.foodchem.2017.07.074

Asofiei, I., Calinescu, I., Trifan, A., and Gavrila, A. I. (2019). A Semi-continuous process for polyphenols extraction from Sea Buckthorn Leaves. Sci. Rep. 9, 1-7. doi: 10.1038/s41598-019-48610-6

Aziz, M., and Karboune, S. (2018). Natural antimicrobial/antioxidant agents in meat and poultry products as well as fruits and vegetables: a review. Crit. Rev. Food Sci. Nutr. 58, 486-511. doi: 10.1080/10408398.2016.119 4256

Basile, A., Sorbo, S., Spadaro, V., Bruno, M., Maggio, A., Faraone, N., et al. (2009). Antimicrobial and antioxidant activities of coumarins from the roots of Ferulago campestris (Apiaceae). Molecules 14, 939-952. doi: $10.3390 /$ molecules 14030939

Bentivegna, S., and Whitney, K. (2002). Subchronic 3-month oral toxicity study of grape seed and grape skin extracts. Food Chem. Toxicol. 40, 1731-1743. doi: 10.1016/S0278-6915(02)00155-2

Bertelli, D., Papotti, G., Bortolotti, L., Marcazzan, G. L., and Plessi, M. (2012). 1HNMR simultaneous identification of health-relevant compounds in propolis extracts. Phytochem. Anal. 23, 260-266. doi: 10.1002/pca.1352 extraction and chemical synthesis for large scale production of environmentally sustainable and cost-effective high-value metabolites in a short time frame to address the increasing demand of the food and nutraceutical market. Thus, phenolic compounds producing GRAS microbes could be promising source as natural food preservatives. Hence, direct or indirect incorporation of these antimicrobial extracts into foods or their packaging materials should be done with caution to ensure consumer safety since safe levels are not fully known. However, the controversial findings from sub-chronic and oral toxicity animal studies require that more detailed safety and efficacy human studies be conducted. Furthermore, extensive research efforts are required to ascertain optimal dosage for safe use in various foods that are beneficial to avoid potential harmful side effects.

\section{AUTHOR CONTRIBUTIONS}

This review manuscript was conceived and written by FO, ED, and FE. FO, ED, and RC revised the manuscript. This work was revised for its intellectual content by BH-L and D-HO. All authors read and approved the final manuscript.

Boncler, M., Golanski, J., Lukasiak, M., Redzynia, M., Dastych, J., and Watala, C. (2017). A new approach for the assessment of the toxicity of polyphenolrich compounds with the use of high content screening analysis. PLoS ONE 12:e0180022. doi: 10.1371/journal.pone.0180022

Bouarab-Chibane, L., Degraeve, P., Ferhout, H., Bouajila, J., and Oulahal, N. (2019a). Plant antimicrobial polyphenols as potential natural food preservatives. J. Sci. Food Agric. 99, 1457-1474. doi: 10.1002/jsfa.9357

Bouarab-Chibane, L., Forquet, V., Lantéri, P., Clément, Y., Léonard-Akkari, L., Oulahal, N., et al. (2019b). Antibacterial properties of polyphenols: characterization and qsar (quantitative structure-activity relationship) models. Front. Microbiol. 10:829. doi: 10.3389/fmicb.2019.00829

Bravo, L. (1998). Polyphenols: chemistry, dietary sources, metabolism, and nutritional significance. Nutr. Rev. 56, 317-333. doi: 10.1111/j.1753-4887.1998.tb01670.x

BröHan, M., Jerkovic, V., and Collin, S. (2011). Potentiality of red sorghum for producing stilbenoid-enriched beers with high antioxidant activity. J. Agric. Food Chem. 59, 4088-4094. doi: 10.1021/jf1047755

Burns, J., Yokota, T., Ashihara, H., Lean, M. E., and Crozier, A. (2002). Plant foods and herbal sources of resveratrol. J. Agric. Food Chem. 50, 3337-3340. doi: $10.1021 /$ jf0112973

Côté, J., Caillet, S., Doyon, G., Dussault, D., Sylvain, J. F., and Lacroix, M. (2011). Antimicrobial effect of cranberry juice and extracts. Food Control 22, 1413-1418. doi: 10.1016/j.foodcont.2011.02.024

Carocho, M., Barreiro, M. F., Morales, P., and Ferreira, I. C. (2014). Adding molecules to food, pros and cons: a review on synthetic and natural food additives. Compr. Rev. Food Sci. Food Saf. 13, 377-399. doi: 10.1111/1541-4337.12065

Catelan, T. B. S., Radai, J. A. S., Leitão, M. M., Branquinho, L. S., de Paula Vasconcelos, P. C., Heredia-Vieira, S. C., et al. (2018). Evaluation of the toxicity and anti-inflammatory activities of the infusion of leaves of Campomanesia guazumifolia (Cambess.) O. Berg. J. Ethnopharmacol. 226, 132-142. doi: 10.1016/j.jep.2018.08.015

Chakthong, S., Weaaryee, P., Puangphet, P., Mahabusarakam, W., Plodpai, P., Voravuthikunchai, S. P., et al. (2012). Alkaloid and coumarins from the green fruits of Aegle marmelos. Phytochemistry 75, 108-113. doi: 10.1016/j.phytochem.2011.11.018 
Chan, P. C., Xia, Q., and Fu, P. P. (2007). Ginkgo biloba leave extract: biological, medicinal, and toxicological effects. J. Environ. Sci. Health C 25, 211-244. doi: 10.1080/10590500701569414

Charradi, K., Mahmoudi, M., Bedhiafi, T., Jebari, K., El May, M. V., Limam, F., et al. (2018). Safety evaluation, anti-oxidative and anti-inflammatory effects of subchronically dietary supplemented high dosing grape seed powder (GSP) to healthy rat. Biomed. Pharmacother. 107, 534-546. doi: 10.1016/j.biopha.2018.08.031

Chen, L. J., Games, D. E., and Jones, J. (2003). Isolation and identification of four flavonoid constituents from the seeds of Oroxylum indicum by high-speed counter-current chromatography. J. Chromatogr. A 988, 95-105. doi: 10.1016/S0021-9673(02)01954-4

Choi, K. R., Jang, W. D., Yang, D., Cho, J. S., Park, D., and Lee, S. Y. (2019). Systems metabolic engineering strategies: integrating systems and synthetic biology with metabolic engineering. Trends Biotechnol. 37, 817-837. doi: 10.1016/j.tibtech.2019.01.003

Chow, H. S., Cai, Y., Hakim, I. A., Crowell, J. A., Shahi, F., Brooks, C. A., et al. (2003). Pharmacokinetics and safety of green tea polyphenols after multipledose administration of epigallocatechin gallate and polyphenon $\mathrm{E}$ in healthy individuals. Clin. Cancer Res. 9, 3312-3319.

Chung, D., Kim, S. Y. and Ahn, J. (2017). Production of three phenylethanoids, tyrosol, hydroxytyrosol, and salidroside, using plant genes expressing in Escherichia coli. Sci. Rep. 7, 1-8. doi: 10.1038/s41598-017-02042-2

Clewell, A. E., Béres, E., Vértesi, A., Glávits, R., Hirka, G., Endres, J. R., et al. (2016). A comprehensive toxicological safety assessment of an extract of Olea europaea L. leaves (bonolive ${ }^{T M}$ ). Int. J. Toxicol. 35, 208-221. doi: $10.1177 / 1091581815619764$

Cory, H., Passarelli, S., Szeto, J., Tamez, M., and Mattei, J. (2018). The role of polyphenols in human health and food systems: a mini-review. Front. Nutr. 5:87. doi: $10.3389 /$ fnut.2018.00087

Counet, C., Callemien, D., and Collin, S. (2006). Chocolate and cocoa: new sources of trans-resveratrol and trans-piceid. Food Chem. 98, 649-657. doi: 10.1016/j.foodchem.2005.06.030

Cowan, M. M. (1999). Plant products as antimicrobial agents. Clin. Microbiol. Rev. 12, 564-582. doi: 10.1128/CMR.12.4.564

Dixon, R. A., and Ferreira, D. (2002). Genistein. Phytochemistry 60, 205-211. doi: 10.1016/S0031-9422(02)00116-4

Duthie, G. G., and Brown, K. M. (1994). "Reducing the risk of cardiovascular disease." in Functional Foods: Designer Foods, Pharmafoods, Nutraceuticals, ed I. Goldberg (New York, NY: Chapman and Hall), 19-38. doi: 10.1007/978-1-4615-2073-3_2

EFSA FEEDAP Panel (EFSA Panel on Additives and Products or Substances used in Animal Feed) (2016). Scientific opinion on the safety and efficacy of dry grape extract when used as a feed flavouring for all animal species and categories. EFSA J. 14:4476. doi: 10.2903/j.efsa.2016.4476

El-Shafey, N. M., and Abdelgawad, H. (2012). Luteolin, a bioactive flavone compound extracted from Cichorium endivia L. subsp. divaricatum alleviates the harmful effect of salinity on maize. Acta Physiol. Plant. 34, 2165-2177. doi: 10.1007/s11738-012-1017-8

Etemadi, A., Sinha, R., Ward, M. H., Graubard, B. I., Inoue-Choi, M., Dawsey, S. M., et al. (2017). Mortality from different causes associated with meat, heme iron, nitrates, and nitrites in the NIH-AARP Diet and Health Study: population based cohort study. BMJ 357:j1957. doi: 10.1136/bmj.j1957

Fantini, M., Benvenuto, M., Masuelli, L., Frajese, G. V., Tresoldi, I., Modesti, A., et al. (2015). In vitro and in vivo antitumoral effects of combinations of polyphenols, or polyphenols and anticancer drugs: perspectives on cancer treatment. Int. J. Mol. Sci. 16, 9236-9282. doi: 10.3390/ijms16059236

Figueredo, K. C., Guex, C. G., Reginato, F. Z., da Silva, A. R. H., Cassanego, G. B., Lhamas, C. L., et al. (2018). Safety assessment of Morus nigra L. leaves: acute and subacute oral toxicity studies in Wistar rats. J. Ethnopharmacol. 224, 290-296. doi: 10.1016/j.jep.2018.05.013

Gadkari, P. V., and Balaraman, M. (2015). Catechins: sources, extraction and encapsulation: a review. Food Bioprod. Process. 93, 122-138. doi: 10.1016/j.fbp.2013.12.004

Galati, G., Lin, A., Sultan, A. M., and O'Brien, P. J. (2006). Cellular and in vivo hepatotoxicity caused by green tea phenolic acids and catechins. Free Rad. Biol. Med. 40, 570-580. doi: 10.1016/j.freeradbiomed.2005. 09.014
Galati, G., Sabzevari, O., Wilson, J. X., and O'brien, P. J. (2002). Prooxidant activity and cellular effects of the phenoxyl radicals of dietary flavonoids and other polyphenolics. Toxicology 177, 91-104. doi: 10.1016/S0300-483X(02)00198-1

Ghosia, L., Asma, S., Kafeel, A., and Jamila, H. (2019). Phytochemical screening, antioxidant and antibacterial properties of daphne mucronata. J. Trad. Chin. Med. 39, 764-771.

Gibbons, S. (2008). Phytochemicals for bacterial resistance-strengths, weaknesses and opportunities. Planta Med. 74, 594-602. doi: 10.1055/s-2008-1074518

Guex, C. G., Reginato, F. Z., Figueredo, K. C., da da Silva, A. R. H., Pires, F. B., da Silva Jesus, R., et al. (2018). Safety assessment of ethanolic extract of Olea europaea L. leaves after acute and subacute administration to Wistar rats. Regul. Toxicol. Pharmacol. 95, 395-399. doi: 10.1016/j.yrtph.2018. 04.013

Hakemi, S. G., Sharififar, F., Haghpanah, T., Babaee, A., and Eftekhar-Vaghefi, S. H. (2019). The effects of olive leaf extract on the testis, sperm quality and testicular germ cell apoptosis in male rats exposed to busulfan. Int. J. Fertil. Steril. 13:57-65. doi: 10.22074/ijfs.2019.5520

Harvey, A. L., Edrada-Ebel, R., and Quinn, R. J. (2015). The re-emergence of natural products for drug discovery in the genomics era. Nat. Rev. Drug Discov. 14, 111-129. doi: $10.1038 / \mathrm{nrd} 4510$

Herrmann, K. M. (1995). The shikimate pathway: early steps in the biosynthesis of aromatic compounds. Plant Cell 7:907. doi: 10.2307/3870046

Isbrucker, R., Edwards, J., Wolz, E., Davidovich, A., and Bausch, J. (2006). Safety studies on epigallocatechin gallate (EGCG) preparations. Part 2: dermal, acute and short-term toxicity studies. Food Chem. Toxicol. 44, 636-650. doi: $10.1016 /$ j.fct.2005.11.003

Jin, S. E., Seo, C. S., Lee, M. Y., Shin, H.-K., Yang, M.-J., and Ha, H. (2018). Sub-chronic toxicity of Gyejibokryeong-hwan in Sprague-Dawley rats. J. Ethnopharmacol. 224, 441-450. doi: 10.1016/j.jep.2018.06.017

Jovanović, A., Petrović, P., Đordević, V., Zdunić, G., Šavikin, K., and Bugarski, B. (2017). Polyphenols extraction from plant sources. Lekovite sirovine 37, 45-49. doi: 10.5937/leksir1737045J

Kallscheuer, N., Vogt, M., and Marienhagen, J. (2016). A novel synthetic pathway enables microbial production of polyphenols independent from the endogenous aromatic amino acid metabolism. ACS Synth. Biol. 6, 410-415. doi: 10.1021/acssynbio.6b00291

Karygianni, L., Cecere, M., Skaltsounis, A. L., Argyropoulou, A., Hellwig, E., Aligiannis, N., et al. (2014). High-level antimicrobial efficacy of representative Mediterranean natural plant extracts against oral microorganisms. Biomed Res. Int. 2014:839019. doi: 10.1155/2014/839019

Kawaii, S., Tomono, Y., Katase, E., Ogawa, K., and Yano, M. (1999). Quantitation of flavonoid constituents in citrus fruits. J. Agric. Food Chem. 47, 3565-3571. doi: $10.1021 /$ jf990153

Kim, E.-H., Kim, S.-L., Kim, S.-H., and Chung, I.-M. (2012). Comparison of isoflavones and anthocyanins in soybean [Glycine max (L.) Merrill] seeds of different planting dates. J. Agric. Food Chem. 60, 10196-10202. doi: $10.1021 / j \mathrm{f} 3031259$

Kim, J.-H., Ahn, D., Eun, J., and Moon, S. (2016). Antioxidant effect of extracts from the coffee residue in raw and cooked meat. Antioxidants 5:21. doi: 10.3390/antiox5030021

Knaggs, A. R. (2001). The biosynthesis of shikimate metabolites. Nat. Prod. Rep. 18, 334-355. doi: 10.1039/b001717p

Kogure, T., and Inui, M. (2018). Recent advances in metabolic engineering of Corynebacterium glutamicum for bioproduction of value-added aromatic chemicals and natural products. Appl. Microbiol. Biotechnol. 102, 8685-8705. doi: 10.1007/s00253-018-9289-6

Kuligowski, M., Pawłowska, K., Jasińska-Kuligowska, I., and Nowak, J. (2017). Isoflavone composition, polyphenols content and antioxidative activity of soybean seeds during tempeh fermentation. CyTA J. Food 15, 27-33. doi: 10.1080/19476337.2016.1197316

Kuorwel, K. K., Cran, M. J., Sonneveld, K., Miltz, J., and Bigger, S. W. (2011). Essential oils and their principal constituents as antimicrobial agents for synthetic packaging films. J. Food Sci. 76, 164-177. doi: 10.1111/j.1750-3841.2011.02384.x

Kurtagić, H., RedŽić, S., Memić, M., and Sulejmanović, J. (2013). Identification and quantification of Quercetin, Naringenin and Hesperetin by RP LC-DAD in honey samples from BandH. Bull. Chem. Technol. Bosnia Herzegovina $40,25-30$. 
Lee, O.-H., and Lee, B.-Y. (2010). Antioxidant and antimicrobial activities of individual and combined phenolics in Olea europaea leaf extract. Bioresour. Technol. 101, 3751-3754. doi: 10.1016/j.biortech.2009.12.052

Leonard, E., Yan, Y., and Koffas, M. A. (2006). Functional expression of a P450 flavonoid hydroxylase for the biosynthesis of plant-specific hydroxylated flavonols in Escherichia coli. Metab. Eng. 8, 172-181. doi: 10.1016/j.ymben.2005.11.001

Li, N., Liu, J.-H., Zhang, J., and Yu, B.-Y. (2008). Comparative evaluation of cytotoxicity and antioxidative activity of 20 flavonoids. J. Agric. Food Chem. 56, 3876-3883. doi: 10.1021/jf073520n

Lien, T. F., Yeh, H. S., and Su, W. T. (2008). Effect of adding extracted hesperetin, naringenin and pectin on egg cholesterol, serum traits and antioxidant activity in laying hens. Arch. Anim. Nutr. 62, 33-43. doi: 10.1080/17450390701780318

Lim, A., Subhan, N., Jazayeri, J. A., John, G., Vanniasinkam, T., and Obied, H. K. (2016). Plant phenols as antibiotic boosters: in vitro interaction of olive leaf phenols with ampicillin. Phytother. Res. 30, 503-509. doi: 10.1002/ptr.5562

Liu, R. H. (2013). Health-promoting components of fruits and vegetables in the diet. Adv. Nutr. 4, 384-392. doi: 10.3945/an.112.003517

Lyons, M. M., Yu, C., Toma, R., Cho, S. Y., Reiboldt, W., Lee, J., et al. (2003). Resveratrol in raw and baked blueberries and bilberries. J. Agric. Food Chem. 51, 5867-5870. doi: 10.1021/jf034150f

Lyu, X., Lee, J., and Chen, W. N. (2019). Potential natural food preservatives and their sustainable production in yeast: terpenoids and polyphenols. J. Agric. Food Chem. 67, 4397-4417. doi: 10.1021/acs.jafc.8b07141

Manach, C., Scalbert, A., Morand, C., Rémésy, C., and Jiménez, L. (2004). Polyphenols: food sources and bioavailability. Am. J. Clin. Nutr. 79, 727-747. doi: $10.1093 /$ ajen/79.5.727

Manas, P., and Pagán, R. (2005). Microbial inactivation by new technologies of food preservation. J. Appl. Microbiol. 98, 1387-1399. doi: $10.1111 / j .1365-2672.2005 .02561 . x$

Markin, D., Duek, L., and Berdicevsky, I. (2003). In vitro antimicrobial activity of olive leaves. Antimikrobielle Wirksamkeit von Olivenblättern in vitro. Mycoses 46, 132-136. doi: 10.1046/j.1439-0507.2003.00859.x

Mazur, W. M., Duke, J. A., Wähälä, K., Rasku, S., and Adlercreutz, H. (1998). Isoflavonoids and lignans in legumes: nutritional and health aspects in humans. J. Nutr. Biochem. 9, 193-200. doi: 10.1016/S0955-2863(97)00184-8

Mazza, G., and Francis, F. (1995). Anthocyanins in grapes and grape products. Crit. Rev. Food Sci. Nutr. 35, 341-371. doi: 10.1080/10408399509527704

Milder, I. E., Arts, I. C., Van De Putte, B., Venema, D. P., and Hollman, P. C. (2005). Lignan contents of Dutch plant foods: a database including lariciresinol, pinoresinol, secoisolariciresinol and matairesinol. Br. J. Nutr. 93, 393-402. doi: 10.1079/BJN20051371

Milner, J., and Goldberg, I. (1994). Functional Foods. London: Chapman and Hall.

Mishima, K., Kawamura, H., Kawakami, R., Ito, S., Inoue, Y., Hirota, T., et al. (2015). Extraction of apigenin and luteolin from leaves of alfalfa (Medicago sativa L.) using mixtures of liquid carbon dioxide and ethanol. Solvent Extr. Res. Dev. 22, 177-186. doi: 10.15261/serdj.22.177

Mullen, W., Archeveque, M.-A., Edwards, C. A., Matsumoto, H., and Crozier, A. (2008). Bioavailability and metabolism of orange juice flavanones in humans: impact of a full-fat yogurt. J. Agric. Food Chem. 56, 11157-11164. doi: $10.1021 /$ jf801974v

Naczk, M., and Shahidi, F. (2004). Extraction and analysis of phenolics in food. J. Chromatogr A 1054, 95-111. doi: 10.1016/S0021-9673(04)01409-8

Ng, K. R., Lyu, X., Mark, R., and Chen, W. N. (2019). Antimicrobial and antioxidant activities of phenolic metabolites from flavonoid-producing yeast: potential as natural food preservatives. Food Chem. 270, 123-129. doi: 10.1016/j.foodchem.2018.07.077

Obied, H. K. (2013). Biography of biophenols: past, present and future. Funct. Foods Health Dis. 3, 230-241. doi: 10.31989/ffhd.v3i6.51

Ofosu, F. K., Elahi, F., Daliri, E. B.-M., Tyagi, A., Chen, X. Q., Chelliah, R., et al. (2020). UHPLC-ESI-QTOF-MS/MS characterization, antioxidant and antidiabetic properties of sorghum grains. Food Chem. 337:127788. doi: 10.1016/j.foodchem.2020.127788

Oketch-Rabah, H. A., Roe, A. L., Rider, C. V., Bonkovsky, H. L., Giancaspro, G. I., Navarro, V., et al. (2020). United States Pharmacopeia (USP) comprehensive review of the hepatotoxicity of green tea extracts. Toxicol. Rep. 7, 386-402. doi: $10.1016 /$ j.toxrep.2020.02.008
Omer, S. A., Elobeid, M., Elamin, M., Hassan, Z., Virk, P., Daghestani, M., et al. (2012). Toxicity of olive leaves (Olea europaea L.) in Wistar albino rats. Asian J. Anim. Vet. Adv. 7, 1175-1182. doi: 10.3923/ajava.2012.1175.1182

Ong, K. L., Kaur, G., Pensupa, N., Uisan, K., and Lin, C. S. K. (2018). Trends in food waste valorization for the production of chemicals, materials and fuels: case study South and Southeast Asia. Bioresour. Technol. 248, 100-112. doi: 10.1016/j.biortech.2017.06.076

Oudah, S. K., Al-Salih, R. M., Gusar, S. H., and Roomi, A. B. (2019). Study of the role of polyphenolic extract of capparis spinosa $\mathrm{L}$. leaves as acute toxicity and antibacterial agent. Plant Arch. 19, 3821-3829.

Ouerfelli, M., Villasante, J., Kaâb, L. B. B., and Almajano, M. P. (2019). Effect of neem (Azadirachta indica L.) on lipid oxidation in raw chilled beef patties. Antioxidants 8:305. doi: 10.3390/antiox8080305

Papuc, C., Goran, G. V., Predescu, C. N., Nicorescu, V., and Stefan, G. (2017). Plant polyphenols as antioxidant and antibacterial agents for shelflife extension of meat and meat products: classification, structures, sources, and action mechanisms. Compr. Rev. Food Sci. Food Saf. 16, 1243-1268. doi: $10.1111 / 1541-4337.12298$

Pasinetti, G. M., and Ho, L. (2010). Role of grape seed polyphenols in Alzheimer's disease neuropathology. Nutr. Diet. 2010, 97-103. doi: 10.2147/NDS.S6898

Peñalvo, J. L., Haajanen, K. M., Botting, N., and Adlercreutz, H. (2005). Quantification of lignans in food using isotope dilution gas chromatography/mass spectrometry. J. Agric. Food Chem. 53, 9342-9347. doi: $10.1021 /$ jf051488w

Pereira, A., Ferreira, I., Marcelino, F., Valentão, P., Andrade, P., Seabra, R., et al. (2007). Phenolic compounds and antimicrobial activity of olive (Olea europaea L. Cv. Cobrançosa) leaves. Molecules 12, 1153-1162. doi: 10.3390/12051153

Pietta, P.-G. (2000). Flavonoids as antioxidants. J. Nat. Prod. 63, 1035-1042. doi: 10.1021/np9904509

Reichling, J. (2018). Plant-microbe interactions and secondary metabolites with antibacterial, antifungal and antiviral properties. Ann. Plant Rev. 39, 214-347. doi: 10.1002/9781119312994.apr0420

Rice-Evans, C. A., Miller, N. J., and Paganga, G. (1996). Structure-antioxidant activity relationships of flavonoids and phenolic acids. Free Rad. Biol. Med. 20, 933-956. doi: 10.1016/0891-5849(95)02227-9

Rico, D., Martin-Diana, A. B., Barat, J., and Barry-Ryan, C. (2007). Extending and measuring the quality of fresh-cut fruit and vegetables: a review. Trends Food Sci. Technol. 18, 373-386. doi: 10.1016/j.tifs.2007.03.011

Rodriguez, A., Strucko, T., Stahlhut, S. G., Kristensen, M., Svenssen, D. K., Forster, J., et al. (2017). Metabolic engineering of yeast for fermentative production of flavonoids. Bioresour. Technol. 245, 1645-1654. doi: 10.1016/j.biortech.2017.06.043

Rodríguez-Vaquero, M. J., Aredes Aredes-Fernández, P., and Manca De Nadra, M. C. (2013). Phenolic compounds from wine as natural preservatives of fish meat. Food Technol. Biotechnol. 51, 376-382.

Rosselli, S., Maggio, A. M., Faraone, N., Spadaro, V., Morris-Natschke, S. L., Bastow, K. F., et al. (2009). The cytotoxic properties of natural coumarins isolated from roots of Ferulago campestris (Apiaceae) and of synthetic ester derivatives of aegelinol. Nat. Prod. Commun. 4:1934578X0900401219. doi: $10.1177 / 1934578 X 0900401219$

Russell, A. (1991). Mechanisms of bacterial resistance to non-antibiotics: food additives and food and pharmaceutical preservatives. J. Appl. Bacteriol. 71, 191-201. doi: 10.1111/j.1365-2672.1991.tb04447.x

Sagdica, O., Aksoyb, A., and Ozkan, G. (2006). Evaluation of the antibacterial and antioxidant potentials of cranberry (Gilaburu, Viburnum Opulus L.) fruit extract. Acta Alimentaria 35, 487-492. doi: 10.1556/AAlim.35.2006.4.12

Salehi, B., Mishra, A. P., Nigam, M., Sener, B., Kilic, M., Sharifi-Rad, M. et al. (2018). Resveratrol: A double-edged sword in health benefits. Biomedicines 6, 91. doi: 10.3390/biomedicines6030091

Sanders, T. H., Mcmichael, R. W., and Hendrix, K. W. (2000). Occurrence of resveratrol in edible peanuts. J. Agric. Food Chem. 48, 1243-1246. doi: 10.1021/jf990737b

Santos, C. N. S., Koffas, M., and Stephanopoulos, G. (2011). Optimization of a heterologous pathway for the production of flavonoids from glucose. Metab. Eng. 13, 392-400. doi: 10.1016/j.ymben.2011.02.002

Savoia, D. (2012). Plant-derived antimicrobial compounds: alternatives to antibiotics. Future Microbiol. 7, 979-990. doi: 10.2217/fmb.12.68 
Schempp, F. M., Drummond, L., Buchhaupt, M., and Schrader, J. (2017). Microbial cell factories for the production of terpenoid flavor and fragrance compounds. J. Agric. Food Chem. 66, 2247-2258. doi: 10.1021/acs.jafc.7b00473

Shao, Z.-H., Hoek, T. L. V., Xie, J., Wojcik, K., Chan, K. C., Li, C.-Q., et al. (2003). Grape seed proanthocyanidins induce pro-oxidant toxicity in cardiomyocytes. Cardiovasc. Toxicol. 3, 331-339. doi: 10.1385/CT:3:4:331

Shoji, T., Akazome, Y., Kanda, T., and Ikeda, M. (2004). The toxicology and safety of apple polyphenol extract. Food Chem. Toxicol. 42, 959-967. doi: 10.1016/j.fct.2004.02.008

Silva, M. M., and Lidon, F. (2016). Food preservatives-an overview on applications and side effects. Emir. J. Food Agric. 26, 366-373. doi: 10.9755/ejfa.2016-04-351

Sivaprakasapillai, B., Edirisinghe, I., Randolph, J., Steinberg, F., and Kappagoda, T. (2009). Effect of grape seed extract on blood pressure in subjects with the metabolic syndrome. Metab. Clin. Exp. 58, 1743-1746. doi: 10.1016/j.metabol.2009.05.030

Smeds, A. I., Eklund, P. C., Sjöholm, R. E., Willför, S. M., Nishibe, S., Deyama, T., et al. (2007). Quantification of a broad spectrum of lignans in cereals, oilseeds, and nuts. J. Agric. Food Chem. 55, 1337-1346. doi: 10.1021/jf0629134

Smeds, A. I., Eklund, P. C., and Willför, S. M. (2012). Content, composition, and stereochemical characterisation of lignans in berries and seeds. Food Chem. 134, 1991-1998. doi: 10.1016/j.foodchem.2012.03.133

Stahlhut, S. G., Siedler, S., Malla, S., Harrison, S. J., Maury, J., Neves, A. R., et al. (2015). Assembly of a novel biosynthetic pathway for production of the plant flavonoid fisetin in Escherichia coli. Metab. Eng. 31, 84-93. doi: 10.1016/j.ymben.2015.07.002

Subhashini, R., Rao, U. M., Sumathi, P., and Gunalan, G. (2010). A comparative phytochemical analysis of cocoa and green tea. Indian J. Sci. Technol. 3, 188-192. doi: 10.17485/ijst/2010/v3i2.3

Sudjana, A. N., D’orazio, C., Ryan, V., Rasool, N., Ng, J., Islam, N., et al. (2009). Antimicrobial activity of commercial Olea europaea (olive) leaf extract. Int. J. Antimicrob. Agents 33, 461-463. doi: 10.1016/j.ijantimicag.2008.10.026

Sun, H., Wang, D., Song, X., Zhang, Y., Ding, W., Peng, X., et al. (2017). Natural prenylchalconaringenins and prenylnaringenins as antidiabetic agents: $\alpha$-glucosidase and $\alpha$-amylase inhibition and in vivo antihyperglycemic and antihyperlipidemic effects. J. Agric. Food Chem. 65, 1574-1581. doi: 10.1021/acs.jafc.6b05445

Suwito, H., Jumina, M., Kristanti, A. N., and Puspaningsih, N. N. T. (2014). Chalcones: synthesis, structure diversity and pharmacological aspects. J. Chem. Pharm. Res. 6, 1078-1088.

Tomas-Navarro, M., Vallejo, F., and Tomas-Barberan, F. A. (2014). "Chapter 40: Bioavailability and metabolism of citrus fruit beverage flavanones in humans," in Polyphenols in Human Health and Disease, eds R. R. Watson, V. R Preedy, and S. Zibadi (San Diego, CA: Academic Press), 537-51. doi: 10.1016/B978-0-12-398456-2.00040-2

Tsao, R. (2010). Chemistry and biochemistry of dietary polyphenols. Nutrients 2 , 1231-1246. doi: 10.3390/nu2121231
Tsao, R., and McCallum, J. (2009). "Chemistry of flavonoids - chapter 5," in Fruit and Vegetable Phytochemicals: Chemistry, Nutritional Value and Stability, eds L. A. de la Rosa, E. Alvarez-Parrilla, and G. Gonzalez-Aguilar (Ames, IA: Blackwell Publishing), 131-53.

Tsao, R., Yang, R., and Young, J. C. (2003). Antioxidant isoflavones in osage orange, Maclura pomifera (Raf.) Schneid. J. Agric. Food Chem. 51, 6445-6451. doi: 10.1021/jf0342369

Unuofin, J. O., Otunola, G. A., and Afolayan, A. J. (2018). Evaluation of acute and subacute toxicity of whole-plant aqueous extract of Vernonia mespilifolia Less. in Wistar rats. J. Integr. Med. 16, 335-341. doi: 10.1016/j.joim.2018. 07.003

Varraso, R., and Camargo, C. A. (2014). Processed meat consumption and lung health: more evidence for harm. Eur. Respir. Soc. 43, 943-946. doi: $10.1183 / 09031936.00228213$

Wang, H.-J., and Murphy, P. A. (1994). Isoflavone content in commercial soybean foods. J. Agric. Food Chem. 42, 1666-1673. doi: 10.1021/jf000 $44 \mathrm{a} 016$

Wang, J., Ho, L., Zhao, W., Ono, K., Rosensweig, C., Chen, L., et al. (2008). Grape-derived polyphenolics prevent $A \beta$ oligomerization and attenuate cognitive deterioration in a mouse model of Alzheimer's disease. J. Neurosci. 28, 6388-6392. doi: 10.1523/JNEUROSCI.036408.2008

Yamakoshi, J., Saito, M., Kataoka, S., and Kikuchi, M. (2002). Safety evaluation of proanthocyanidin-rich extract from grape seeds. Food Chem. Toxicol. 40, 599-607. doi: 10.1016/S0278-6915(02)00006-6

Zaveri, N. T. (2006). Green tea and its polyphenolic catechins: medicinal uses in cancer and noncancer applications. Life Sci. 78, 2073-2080. doi: 10.1016/j.lfs.2005.12.006

Zhang, N. L., Zhu, Y. H., Huang, R. M., Fu, M. Q., Su, Z. W., Cai, J. Z., et al. (2012). Two new stilbenoids from Cajanus cajan. Zeitschrift für Naturforschung B 67, 1314-1318. doi: 10.5560/znb.2012-0184

Zhao, Y.-J., and Li, C. (2018). Biosynthesis of plant triterpenoid saponins in microbial cell factories. J. Agric. Food Chem. 66, 12155-12165. doi: 10.1021/acs.jafc.8b04657

Conflict of Interest: The authors declare that the research was conducted in the absence of any commercial or financial relationships that could be construed as a potential conflict of interest.

Copyright (c) 2020 Ofosu, Daliri, Elahi, Chelliah, Lee and Oh. This is an open-access article distributed under the terms of the Creative Commons Attribution License (CC $B Y)$. The use, distribution or reproduction in other forums is permitted, provided the original author(s) and the copyright owner(s) are credited and that the original publication in this journal is cited, in accordance with accepted academic practice. No use, distribution or reproduction is permitted which does not comply with these terms. 